\title{
Acute- phase response and iron status markers among pulmonary tuberculosis patients: a cross-sectional study in Mwanza, Tanzania
}

\author{
Henrik Friis $^{1}{ }^{*}$, Nyagosya Range ${ }^{2}$, Camilla Brændgaard Kristensen ${ }^{1}$, Pernille Kæstel ${ }^{1}$, John Changalucha ${ }^{3}$, \\ Wabyahe Malenganisho ${ }^{3}$, Henrik Krarup ${ }^{4}$, Pascal Magnussen ${ }^{5}$ and Åse Bengaard Andersen ${ }^{6}$ \\ ${ }^{1}$ Department of Human Nutrition, Faculty of Life Sciences, University of Copenhagen, Rolighedsvej 30, 1958 Frederiksberg C, \\ Copenhagen, Denmark \\ ${ }^{2}$ National Institute for Medical Research, Muhimbili Medical Research Centre, Dar es Salaam, Tanzania \\ ${ }^{3}$ National Institute for Medical Research, Mwanza Medical Research Centre, Mwanza, Tanzania \\ ${ }^{4}$ Department of Clinical Biochemistry, Aalborg University Hospital, Aalborg, Denmark \\ ${ }^{5}$ DBL - Centre for Health Research and Development, Department of Veterinary Pathobiology, Faculty of Life Sciences, \\ University of Copenhagen, Copenhagen, Denmark \\ ${ }^{6}$ Department of Infectious Diseases, Rigshospitalet, University of Copenhagen, Copenhagen, Denmark
}

(Received 3 June 2008 - Revised 4 November 2008 - Accepted 5 November 2008 - First published online 28 January 2009)

Fe status is difficult to assess in the presence of infections. To assess the role of the acute- phase response (APR) and other predictors of serum ferritin and transferrin receptor, we conducted a cross-sectional study among pulmonary tuberculosis (PTB) patients in Mwanza, Tanzania. The acute- (serum ferritin) phase protein, serum $\alpha_{1}$-antichymotrypsin (ACT) and serum ferritin and serum soluble transferrin receptor (sTfR) were measured, and data on smoking, soil and alcohol intake, and infection status were collected. Linear regression analysis was used to assess the role of elevated serum ACT and other predictors of serum ferritin and serum sTfR. Of 655 patients, $81.2 \%$ were sputum positive (PTB+) and 47.2\% HIV+. Mean serum ACT was $0.72 \mathrm{~g} / 1$, with $91.1 \%$ above $0.4 \mathrm{~g} / 1$. Among females and males, respectively, geometric mean serum ferritin was 140.9 and $269.1 \mu \mathrm{g} / 1(P<0 \cdot 001)$, and mean serum sTfR 4.3 and $3.8 \mathrm{mg} / 1(P<0 \cdot 001)$. Serum sTfR was increased $0.5 \mathrm{mg} / 1$ and log serum ferritin increased linearly with serum ACT $>0.4 \mathrm{~g} / \mathrm{l}$. PTB + and HIV infection, alcohol drinking and smoking were the positive predictors of serum ferritin, and female sex, soil eating, Schistosoma mansoni and hookworm infection were the negative predictors. Similarly, smoking and HIV infection were the negative predictors of serum sTfR, and female sex, soil eating and PTB + were the positive predictors. Serum ferritin and serum sTfR are affected by the APR, but may still provide information about Fe status. It may be possible to develop algorithms, based on the markers of the APR and Fe status, to assess the Fe status among the patients with tuberculosis or other infections eliciting an APR.

Pulmonary tuberculosis: HIV: Ferritin: Transferrin receptor: Acute- phase response: Tanzania

Infections often precipitate a substantial acute- phase response (APR), which leads to the sequestration of Fe, Fe-limited erythropoiesis and anaemia of inflammation. In such patients, it is difficult to assess to what extent Fe deficiency contributes to the anaemia.

Ferritin, an Fe-storage protein that circulates in small quantities proportional to the amount of $\mathrm{Fe}$ in the stores is the best measure of storage $\mathrm{Fe}^{(1,2)}$, but is not valid as a measure of storage $\mathrm{Fe}$ during conditions eliciting an $\mathrm{APR}^{(3)}$. Soluble transferrin receptors (sTfR), expressed on the cell membranes to receive Fe from circulating transferrin, are up-regulated when Fe is lacking in the cytosol. Since sTfR are present in serum, proportional to the amount expressed on cell membranes, serum sTfR is considered a useful marker of Fe deficiency $^{(4)}$. It has been argued that serum sTfR is unaffected by the $\mathrm{APR}^{(4)}$, but recent studies suggest the opposite ${ }^{(5,6)}$.
The serum concentration of the acute- phase reactants, such as C-reactive protein, $\alpha_{1}$-acid glycoprotein and $\alpha$-antichymotryp$\sin$ (ACT), has been used to adjust for the effect of the APR on the markers of status with respect to $\mathrm{Fe}$ and other micronutrients, when assessing the prevalence of deficiency in an apparently healthy population ${ }^{(7)}$. The acute- phase reactants differ with respect to magnitude, timing and duration of the response, with ACT and $\alpha_{1}$-acid glycoprotein having a more delayed response, and a combination of the acute- phase reactants may be needed to account for different stages of the response ${ }^{(8)}$.

However, it may also be of interest to assess the Fe status in a clinical setting, among the patients with more massive APR. As part of a trial among pulmonary tuberculosis patients in Tanzania ${ }^{(9,10)}$, we collected cross-sectional data on nutritional status. In the present paper, we present data on the role of the APR and other predictors of serum ferritin and sTfR.

Abbreviations: ACT, $\alpha$-antichymotrypsin; APR, acute- phase response; epg, eggs per gram; PTB, pulmonary tuberculosis; sTfR, soluble transferrin receptor. * Corresponding author: Dr Henrik Friis, fax +45 3533 2483, email hfr@life.ku.dk 


\section{Subject and methods}

\section{Study area and population}

The study was conducted in Mwanza region, Tanzania, between August 2001 and July 2002, within the framework of the National Tuberculosis and Leprosy Programme ${ }^{(11)}$. In brief, tuberculosis suspects attending in- and out-patient clinics at each of five recruitment centres were examined, diagnosed and treated in accordance with the recommended standard procedures ${ }^{(12)}$. Those diagnosed as smear-positive or smear-negative pulmonary tuberculosis (PTB) cases, based on the routine examination of three sputum specimens (spot, morning and spot) for acid-fast bacilli using the Ziehl-Neelsen staining technique, were all offered anti-tuberculosis treatment. Before the start of the treatment, these patients were offered inclusion in the study if aged 15 years or above and if considered a new or relapse case. After informed consent, all the participants were requested to submit a morning sputum specimen in a sterile universal bottle for confirmation at the Zonal tuberculosis Reference Laboratory at Bugando Medical Centre, using microscopy after fluorochrome (auramine O) staining and culture on Lowenstein-Jensen solid media ${ }^{(13)}$. For the purpose of the present study, only those found positive by microscopy (auramine $\mathrm{O}$ staining) or culture at the Zonal Tuberculosis Reference Laboratory were considered sputum-positive pulmonary tuberculosis patients $(\mathrm{PTB}+)$. Those not found positive by microscopy after auramine $\mathrm{O}$ staining or by culture at the Zonal Tuberculosis Reference Laboratory were considered sputum-negative tuberculosis patients (PTB-) if history, clinical manifestations and X-ray were indicative of tuberculosis according to the WHO guidelines ${ }^{(12)}$.

\section{Methods}

Before the start of the tuberculosis treatment, questionnaire data on socio-demography, smoking, alcohol and soil consumption, and medical history were obtained from each patient.

Stool and urine samples were also taken for two consecutive days. Duplicate $50 \mathrm{mg}$ Kato thick smears were made from each stool sample, covered with cellophane soaked in glycerine and malachite green, and examined for Schistosoma mansoni and geohelminths (i.e. hookworm, Ascaris lumbricoides, Trichuris trichiura, Strongyloides stercoralis) eggs ${ }^{(14)}$. The mean egg counts of the two slides were computed and then multiplied by 20 to obtain the number of eggs per gram (epg) of faeces, which is referred to as the intensity of infection. Urine specimens were collected and examined for Schistosoma haematobium using the filtration technique with Nuclepore ${ }^{\circledR}$ membranes ${ }^{(15)}$. The predominant hookworm species in the area was known to be Necator americanus ${ }^{(16)}$.

A blood sample was taken from the cubital vein between 08.00 and 12.00 hours, and $\mathrm{Hb}$ was determined using a portable haemoglobinometer (HemoCue ${ }^{\mathrm{TM}}$; Angelholm, Sweden). Anaemia was defined as $\mathrm{Hb}<120 \mathrm{~g} / \mathrm{l}$ for women and $<130 \mathrm{~g} / \mathrm{l}$ for men ${ }^{(17)}$. Furthermore, thick and thin blood smears were prepared and stained with Giemsa's stain, and examined for malaria parasites. HIV testing was done using two enzyme immunological assays. Samples found negative using UNIFORM I Vironostika HIV-MIXT (Organon, Boxtel, The Netherlands) were considered negative, whereas those found positive or indeterminate were tested with a confirmatory enzyme immunological assays, UNIFORM II, Enzygnost anti-HIV-1/HIV-2 (Behring, Marburg, Germany). The samples found anti-HIV positive were then tested for HIV-1 using a modification of an inhouse-developed RT-PCR ${ }^{(18)}$.

From the remaining blood, serum was separated and kept at $-70^{\circ} \mathrm{C}$ until further analyses. Serum ferritin, ACT and sTfR were determined at the Department of Human Nutrition, University of Copenhagen, Denmark.

Serum ACT was measured by automated turbidimetry (Cobas Mira Plus, Roche, Montclair, NJ, USA). Rabbit antihuman ACT (catalogue no. Q 0367, DAKO, Glostrup, Denmark) was used to precipitate ACT and turbidity was measured at $345 \mathrm{~nm}$ after incubation for $8.3 \mathrm{~min}$ at $37^{\circ} \mathrm{C}$. The results are given as $\mathrm{g} / \mathrm{l}$ serum based on a standard curve in the range 0.05-1.24 g/l (DAKO, cat. no. X0908). The samples with values above the reference range were diluted appropriately. The inter-run variation was $3 \% \mathrm{CV}$. The accuracy was validated against high and low commercial controls (DAKO, cat. no. X0940 and X0939). The values above 0.4 g/1 were considered elevated ${ }^{(19)}$. Serum ferritin was measured by a fluoroimmunoassay kit (DELFIA Ferritin; Wallac, Turku, Finland). Detection limit of the method was $0.5 \mu \mathrm{g} / \mathrm{l}$ and inter-run variation was $5 \% \mathrm{CV}$.

Serum concentration of STfR was measured by an automated turbidimetry kit (IdeA sTfR-IT, cat. no. 67 968, Orion Diagnostica, Espoo, Finland) analysed with Cobas Mira Plus, Roche. Serum sTfR was precipitated with sheep anti-human sTfR and turbidity was measured at $600 \mathrm{~nm}$ after incubation for $9 \mathrm{~min}$ at $37^{\circ} \mathrm{C}$. The results are given as $\mathrm{mg} / \mathrm{l}$ serum based on a standard curve in the range $0.3-8.5 \mathrm{mg} / \mathrm{l}$ Inter-run variation was $8 \% \mathrm{CV}$. The accuracy was validated against high and low commercial controls (Orion Diagnostica no. 67975 and 67976). According to the manufacturer, the values above $1.9 \mathrm{mg} / \mathrm{l}$ were considered elevated.

\section{Ethical consideration}

The Ethics Committee of the National Institute for Medical Research in Tanzania granted permission to conduct the study, and the Danish Central Medical Ethics Committee in Denmark approved it. Oral informed consent was obtained from all study participants before inclusion. The patients diagnosed with helminth or malaria infections and anaemia were referred for the treatment. Pre-HIV test counselling was given to all participants; post-test counselling was offered to those who wanted to know their HIV results.

\section{Statistical analysis}

Normal probability plots were used to assess the distribution of continuous variables. Data on serum ferritin was $\log (\mathrm{x})$ transformed to achieve approximate normal distributions. The two-sample $t$ test or one-way ANOVA were used to test for the differences in the means between two or more groups, respectively, while the $\chi^{2}$ test was used to test for the differences in the proportions. Linear regression analyses were used to identify the predictors of serum ferritin and serum sTfR. The variables assessed were sex, smoking, consumption of alcohol and soil, PTB and HIV status, and 
S. mansoni and hookworm infections, with and without adjustment for elevated serum ACT using dummy variables based on the categories $0 \cdot 4-0 \cdot 6,0 \cdot 6-0 \cdot 8,0 \cdot 8-1 \cdot 0$ and above $1 \cdot 0 \mathrm{~g} / \mathrm{l}$, using the values $<0.4 \mathrm{~g} / 1$ as reference. Age was adjusted for using dummy variables with age $<20$ years as reference, but not shown. The variables with $P<0.10$ were kept in the model, and those with $P<0.05$ were considered significant. Normal and residual $v$. fitted plots were examined to assess the normality and homoscedasticity of residuals. Stata version 9.0 (StataCorp, College Station, TX, USA) was used for all analyses.

\section{Results}

Of 655 PTB patients, $81.2 \%$ were PTB+ and $18.8 \%$ PTB $-{ }^{(20)}$. The prevalence of HIV co-infection was $47.2 \%$, with $43.6 \%$ among the PTB+ patients and $62.6 \%$ among the PTB - patients. Half $(49.5 \%)$ of the males and $4.8 \%$ of the females reported smoking. Regular alcohol consumption was reported by $25.1 \%$ of the females and $42.2 \%$ of the males. Regular soil eating was reported by $10.0 \%$ of the females and $0.8 \%$ of the males.

Schistosoma mansoni egg output was found in $34.4 \%$ of the patients. In those infected, the geometric mean egg output was $34 \mathrm{epg}$, and $24 \%$ had intensities above 100 epg, indicating moderate and heavy intensities ${ }^{(21)}$. The prevalence of hookworm infection was $18.0 \%$. In those infected, the geometric mean egg output was $88 \mathrm{epg}$, and only $2 \%$ had intensities above $2000 \mathrm{epg}$, used to define moderate or heavy infections $^{(21)}$. Other helminth infections (S. haematobium, A. lumbricoides, $T$. trichiura, $S$. stercoralis) as well as malaria parasitaemia were less common, with prevalences below $5 \%$.

\section{Acute-phase response}

The mean serum ACT was $0.72 \mathrm{~g} / \mathrm{l}$, with only $8.9 \%$ of the patients having values below $0.4 \mathrm{~g} / \mathrm{l}$, and with $16.6 \%$ above $1.0 \mathrm{~g} / \mathrm{l}$. There was no difference between the males and females $(0.74$ v. $0.73 \mathrm{~g} / \mathrm{l}, P=0.37)$. The PTB + patients had $0.15 \mathrm{~g} / \mathrm{l}(95 \%$ CI $0 \cdot 10,0.20)$ higher mean serum ACT compared with the PTB - ones $(0.76$ v. $0.61 \mathrm{~g} / 1, P<0.001)$ : among the PTB - patients $21.7 \%$ had serum ACT below $0.4 \mathrm{~g} / \mathrm{l}$ and $11.6 \%$ above $1.0 \mathrm{~g} / \mathrm{l}$, compared with only $4.2 \%$ and $20.2 \%$, respectively, among the PTB+ ones. Furthermore, among the PTB + patients, serum ACT increased with culture intensity as it was 0.70 (95\% CI $0.56,0.65), 0.73$
(95\% CI $0.68,0.78)$ and $0.80(95 \%$ CI $0.78,0.82) \mathrm{g} / 1$ among those with mild, moderate and severe culture intensities ( $P$ for trend $<0 \cdot 001$ ). Current smokers had $0.07 \mathrm{~g} / \mathrm{l}$ (95\% CI 0.01, 0.12) higher serum ACT than non-smokers, but previous smokers did not have higher serum ACT (0.006, $95 \%$ CI $-0.4,0.06)$. There was no difference in serum ACT between the patients with or without HIV co-infection $(0.02 \mathrm{~g} / \mathrm{l}, 95 \% \mathrm{CI}-0.02,0.06)$.

\section{$\mathrm{Hb}$ and markers of iron status}

$\mathrm{Hb}$ was $16.5 \mathrm{~g} / \mathrm{l}(95 \% \mathrm{CI} 12.8,20 \cdot 3)$ higher among the males compared with the females (Table 1). Similarly, geometric mean serum ferritin was $1.9(95 \%$ CI $1.6,2.3)$ times higher in the males, and mean serum sTfR was $0.47 \mathrm{mg} / 1(95 \%$ CI $0.24,0.71)$ higher in the females. As shown in Fig. 1, serum sTfR declined with increasing log serum ferritin, and levelled off when the latter was above $1.5 \log$ or $31.6 \mu \mathrm{g} / \mathrm{l}$, similarly for the females and males (not shown).

Among the males, $\mathrm{Hb}$ was $6.0 \mathrm{~g} / \mathrm{l}(95 \% \mathrm{CI}-0 \cdot 4,12 \cdot 5)$ lower and the prevalence of anaemia was $7.9 \%$ (95\% CI $2.6,18.5)$ higher among the PTB+ patients compared with the PTBones, whereas there were no differences among the females (Table 2). Similarly, among the males, geometric mean serum ferritin was $1.4(95 \%$ CI $1.1,1.9)$ times higher among the $\mathrm{PTB}+$ patients compared with the PTB - ones, whereas there were no differences among the females (95\% CI 0.6, 1.3). The $\mathrm{PTB}+$ patients compared with the $\mathrm{PTB}-$ ones had higher mean serum sTfR in both the females $(0.68 \mathrm{mg} / 1,95 \% \mathrm{CI}$ $0.20,1.15)$ and the males $(0.41 \mathrm{mg} / \mathrm{l}, 95 \%$ CI $0.03,0.78)$. HIV+ compared with HIV - had lower Hb among both the females $(7.6 \mathrm{~g} / \mathrm{l}, 95 \% \mathrm{CI} 2 \cdot 2,13.0)$ and the males $(15.6 \mathrm{~g} / \mathrm{l}$, $95 \%$ CI 10.8, 20.4; Table 2). Similarly, geometric mean serum ferritin was 1.8 times (95\% CI 1.4, 2.4) higher among the $\mathrm{HIV}+$ compared with the HIV - in the females, and 2.0 times (95\% CI 1.6, 2.5) higher in the males. Accordingly, serum sTfR was lower among the HIV+ compared with the HIVamong the females $(0.68 \mathrm{mg} / \mathrm{l}, 95 \%$ CI $0.30,1.05)$, but not among the males $(-0.03,95 \% \mathrm{CI}-0.33,0 \cdot 26)$.

$\mathrm{Hb}$ declined and geometric mean serum ferritin increased with increasing serum ACT (Table 3), both among the females and males, whereas there was no significant difference in serum sTfR across the categories of serum ACT. Log serum ferritin was approximately 1.8 or $63.1 \mu \mathrm{g} / \mathrm{l}$ when serum ACT was below $0.4 \mathrm{~g} / \mathrm{l}$, but then increased linearly with increasing

Table 1. Markers of $\mathrm{Hb}$ and iron status among 655 tuberculosis patients by sex (Mean values and $95 \%$ confidence intervals)

\begin{tabular}{|c|c|c|c|c|c|}
\hline & \multicolumn{2}{|c|}{ Females ( $n$ 271) } & \multicolumn{2}{|c|}{ Males ( $n$ 383) } & \multirow[b]{2}{*}{$P$} \\
\hline & Mean & $95 \% \mathrm{Cl}$ & Mean & $95 \% \mathrm{Cl}$ & \\
\hline $\mathrm{Hb}(\mathrm{g} / \mathrm{l})$ & $95 \cdot 4$ & $92 \cdot 7,98 \cdot 1$ & 111.9 & $109 \cdot 4,114 \cdot 4$ & $<0.001$ \\
\hline Anaemia $(\%)^{*}$ & $85 \cdot 6$ & $81 \cdot 4,89 \cdot 8$ & $77 \cdot 3$ & $73 \cdot 1,81 \cdot 5$ & 0.008 \\
\hline Serum ferritin $(\mu \mathrm{g} / \mathrm{l}) \dagger$ & $140 \cdot 9$ & $122 \cdot 7,161 \cdot 7$ & $269 \cdot 1$ & $241 \cdot 4,300 \cdot 1$ & $<0.001$ \\
\hline$<24(\%)$ & \multicolumn{2}{|c|}{8.5} & \multicolumn{2}{|c|}{2.9} & $<0.001$ \\
\hline Serum sTfR (mg/l) & $4 \cdot 3$ & $4 \cdot 1,4 \cdot 5$ & $3 \cdot 8$ & $3 \cdot 7,4 \cdot 0$ & $<0.001$ \\
\hline$>1.9(\%)$ & \multicolumn{2}{|c|}{3.0} & \multicolumn{2}{|c|}{4.0} & 0.50 \\
\hline
\end{tabular}

sTfR, soluble transferrin receptor.

${ }^{\star}$ Defined as $\mathrm{Hb}<120 \mathrm{~g} / \mathrm{l}$ for females and $<130 \mathrm{~g} / \mathrm{l}$ for males.

† Geometric mean $(95 \% \mathrm{Cl})$. 


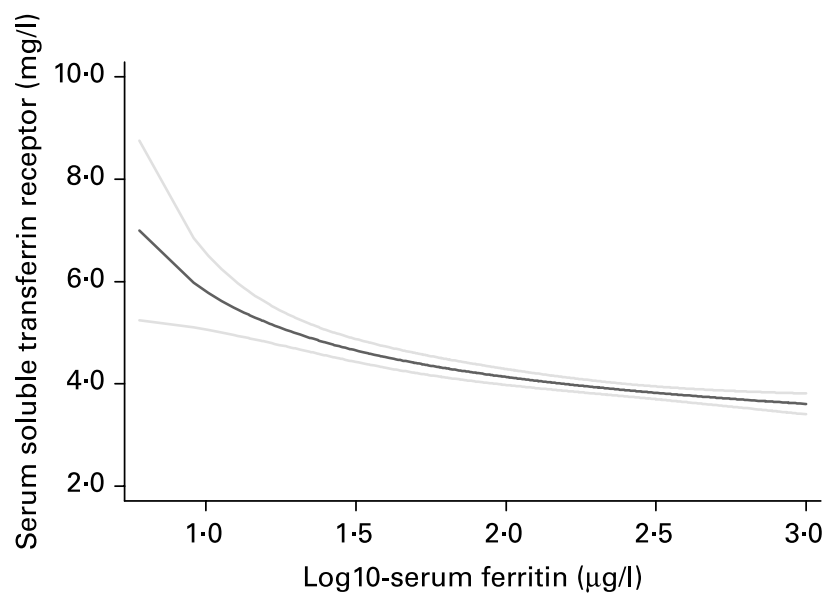

Fig. 1. Fractional polynomial plot of the relationship between serum soluble

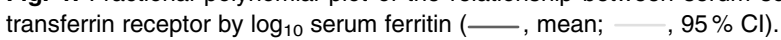

serum ACT. By contrast, serum sTfR increased with serum ACT increasing up to $0.4 \mathrm{~g} / \mathrm{l}$ and reached a plateau (not shown).

The role of smoking, soil eating, alcohol consumption, as well as infection with hookworm and $S$. mansoni were also assessed. Among the males, current smokers had significantly lower serum sTfR $(3.4 \mathrm{mg} / \mathrm{l})$ than non-smokers $(3.9 \mathrm{mg} / \mathrm{l})$ and previous $(3.9 \mathrm{mg} / \mathrm{l})$ smokers (one-way ANOVA, $P=0.009)$. By contrast, there were no associations between smoking status and $\mathrm{Hb}$ and serum ferritin. Among the females, those eating soil had $0.44(95 \%$ CI $0.28,0.69)$ times lower serum ferritin than those not eating soil $(66.1 \quad v .151 .4 \mu \mathrm{g} / \mathrm{l}$, $P<0.001$ ), whereas there were no differences in $\mathrm{Hb}$ and serum sTfR. Due to the low numbers, the effect of smoking and soil eating could not be assessed in the females and males, respectively. Alcohol consumption was associated with $4.1 \mathrm{~g} / \mathrm{l}(95 \% \mathrm{CI} 0 \cdot 1,8 \cdot 2, P=0.046)$ higher $\mathrm{Hb}, 1.55$ (95\% CI 1.29, 1.86, $P<0.001)$ times higher serum ferritin and $0.4 \mathrm{mg} / 1(95 \%$ CI $0.2,0.7, P<0.001)$ lower serum sTfR, both among the males and females (not shown). Hookworm infection was associated with 6.1 (95\% CI $1.0,11 \cdot 1$, $P=0.02) \mathrm{g} / \mathrm{l}$ lower $\mathrm{Hb}, 0.63$ (95\% CI $0.500 .80, P<0.001)$ times lower serum ferritin and 0.37 (95\% CI 0.06, 0.70, $P=0.02) \mathrm{mg} / \mathrm{l}$ higher serum sTfR. By contrast, $S$. mansoni infection was associated with 0.80 (95\% CI 0.66, 0.96, $P=0.02)$ times lower serum ferritin (176 v. $221 \mu \mathrm{g} / \mathrm{l})$, but not $\mathrm{Hb}$ and serum sTfR.

\section{Predictors of serum ferritin and soluble transferrin receptor}

The role of sex, infectious disease (PTB, HIV, hookworm, S. mansoni) status, alcohol consumption, smoking and soil eating as the predictors of serum ferritin and sTfR was assessed in linear regression models, without and with adjustment for elevated serum ACT. Since there were no interactions between sex and other potential predictors, the analyses were done for the females and males combined.

For serum ferritin (Table 4), negative predictors were female sex, soil eating, $S$. mansoni and hookworm infection, and positive predictors were alcohol consumption and smoking, sputum-positive tuberculosis and HIV infection. With these predictors in the model (model 1), $24 \%$ of the variation in serum ferritin was explained. Compared with the overall geometric mean serum ferritin of $205.7 \mu \mathrm{g} / \mathrm{l}$, the geometric mean serum ferritin among the individuals falling into all the reference categories (the intercept), i.e. females, not smoking, drinking alcohol and eating soil, and PTB - and uninfected with HIV, S. mansoni and hookworm, was $137.4 \mu \mathrm{g} / \mathrm{l}$. Elevated serum ACT was strongly associated with serum ferritin, in that serum ferritin was $1.44,2.75,4.00$ and 6.50 times higher in those with serum ACT between 0.4-0.6, 0.6-0.8, $0.8-1.0$ and above $1.0 \mathrm{~g} / \mathrm{l}$. Introducing elevated serum ACT to the model (model 2) explained the effect of sputum-positive tuberculosis (PTB+; $10^{\mathrm{B}}$ fell from 1.51 to 1.06$)$, but not of HIV infection. Furthermore, it seemed to have explained some of the effects of $S$. mansoni, but none of the effects of

Table 2. Markers of $\mathrm{Hb}$ and iron status among 655 tuberculosis patients by tuberculosis and HIV status

(Mean values and $95 \%$ confidence intervals)

\begin{tabular}{|c|c|c|c|c|c|c|c|c|c|c|}
\hline & \multicolumn{5}{|c|}{ Pulmonary tuberculosis* } & \multicolumn{5}{|c|}{ HIV infection } \\
\hline & \multicolumn{2}{|r|}{ PTB +} & \multicolumn{2}{|r|}{ PTB- } & \multirow[b]{2}{*}{$P$} & \multicolumn{2}{|r|}{$\mathrm{HIV}+$} & \multicolumn{2}{|r|}{$\mathrm{HIV}-$} & \multirow[b]{2}{*}{$P$} \\
\hline & Mean & $95 \% \mathrm{Cl}$ & Mean & $95 \% \mathrm{Cl}$ & & Mean & $95 \% \mathrm{Cl}$ & Mean & $95 \% \mathrm{Cl}$ & \\
\hline Females & \multicolumn{2}{|c|}{$(n 218)$} & \multicolumn{2}{|c|}{$(n 53)$} & & \multicolumn{2}{|c|}{$(n$ 128) } & \multicolumn{2}{|c|}{$(n$ 143) } & \\
\hline $\mathrm{Hb}(\mathrm{g} / \mathrm{l})$ & $95 \cdot 7$ & $92 \cdot 9,98.5$ & 94.1 & $86 \cdot 2,102 \cdot 0$ & 0.65 & 91.8 & $87 \cdot 9,95 \cdot 7$ & 99.4 & $95 \cdot 7,103 \cdot 1$ & 0.006 \\
\hline$<120(\%)$ & $87 \cdot 2$ & $92 \cdot 5,99 \cdot 1$ & $79 \cdot 2$ & $89.5,98.0$ & 0.14 & $88 \cdot 1$ & $82 \cdot 7,93 \cdot 5$ & $82 \cdot 8$ & $76 \cdot 2,89 \cdot 4$ & 0.22 \\
\hline Serum ferritin $(\mu \mathrm{g} / \mathrm{l}) \dagger$ & \multirow{2}{*}{\multicolumn{2}{|c|}{$\begin{array}{c}143.8{ }^{123.5,16 / .5} \\
8.3\end{array}$}} & $128 \cdot 8$ & $92 \cdot 5,180 \cdot 3$ & 0.55 & $187 \cdot 8$ & $156 \cdot 8,224 \cdot 9$ & $102 \cdot 2$ & $83 \cdot 7,124 \cdot 7$ & $<0.001$ \\
\hline$<24(\%)$ & & & \multicolumn{2}{|c|}{9.4} & 0.78 & \multicolumn{2}{|r|}{3.5} & \multicolumn{2}{|c|}{$14 \cdot 1$} & $<0.002$ \\
\hline $\begin{array}{l}\text { Serum sTfR }(\mathrm{mg} / \mathrm{l}) \dagger \\
>1.9(\%)\end{array}$ & 4.4 & $0.9^{4 \cdot 2,4 \cdot 6}$ & \multicolumn{2}{|r|}{$11 \cdot 3$} & $\begin{array}{r}0.005 \\
<0.001\end{array}$ & \multicolumn{2}{|r|}{$2 \cdot 8$} & \multicolumn{2}{|r|}{3.1} & $\begin{array}{c}<0.001 \\
0.87\end{array}$ \\
\hline Males & \multicolumn{2}{|r|}{$(n 313)$} & \multicolumn{2}{|c|}{$(n 70)$} & & \multicolumn{2}{|c|}{$(n+166)$} & \multicolumn{2}{|c|}{$(n 218)$} & \\
\hline $\begin{array}{l}\mathrm{Hb}(\mathrm{g} / \mathrm{l}) \\
\quad<130(\%)\end{array}$ & $\begin{array}{r}110 \cdot 8 \\
80 \cdot 2\end{array}$ & $\begin{array}{c}108 \cdot 1,113 \cdot 5 \\
75 \cdot 8,84 \cdot 6\end{array}$ & $\begin{array}{r}116 \cdot 8 \\
64 \cdot 3\end{array}$ & $\begin{array}{c}110 \cdot 4,123 \cdot 2 \\
52 \cdot 8,75 \cdot 8\end{array}$ & $\begin{array}{l}0.07 \\
0.004\end{array}$ & $\begin{array}{r}103.0 \\
88.5\end{array}$ & $\begin{array}{l}99 \cdot 4,106 \cdot 6 \\
83 \cdot 6,93 \cdot 4\end{array}$ & $\begin{array}{r}118.6 \\
68.8\end{array}$ & $\begin{array}{c}115 \cdot 4,121 \cdot 8 \\
62 \cdot 6,75 \cdot 0\end{array}$ & $\begin{array}{l}<0.001 \\
<0.001\end{array}$ \\
\hline $\begin{array}{l}\text { Serum ferritin }(\mu \mathrm{g} / \mathrm{l}) \dagger \\
\quad<24(\%)\end{array}$ & \multicolumn{2}{|c|}{2.9} & $197 \cdot 7$ & $\begin{array}{l}148 \cdot 9,262 \cdot 4 \\
2 \cdot 9^{-1}\end{array}$ & $\begin{array}{l}0.009 \\
0.99\end{array}$ & & $\begin{array}{l}343 \cdot 3,463 \cdot 9 \\
1 \cdot 2^{-3}\end{array}$ & \multicolumn{2}{|c|}{$4 \cdot 2$} & $\begin{array}{l}<0.001 \\
<0.09\end{array}$ \\
\hline $\begin{array}{l}\text { Serum sTfR }(\mathrm{mg} / \mathrm{l}) \\
\quad>1.9(\%)\end{array}$ & $3 \cdot 9$ & $2 \cdot 9^{3 \cdot 7,4 \cdot 0}$ & 3.5 & 8.7 & $\begin{array}{l}0.03 \\
0.03\end{array}$ & \multicolumn{2}{|r|}{$6 \cdot 0$} & & $2 \cdot 3^{3 \cdot 6,4 \cdot 0}$ & $\begin{array}{l}0.82 \\
0.07\end{array}$ \\
\hline
\end{tabular}

sTfR, soluble transferrin receptor.

* Tuberculosis patients are categorised as PTB + if mycobacteria were detected in sputum, and PTB - if not.

† Geometric mean $(95 \% \mathrm{Cl})$. 
hookworm infection. Also, some of the effects of current, but not past, smoking seemed to have been explained. The intercept fell to $60.3 \mu \mathrm{g} / \mathrm{l}$ and the proportion of the variation explained increased from 0.24 to 0.47 . If tuberculosis culture intensity were included, instead of PTB as a dichotomous variable, then mild, moderate and severe intensities were associated with $1.32(95 \%$ CI $1.03,1.70), 1.53$ (95\% CI 1.12 , $2.04)$ and $1.62(95 \%$ CI $1.30,2.00)$ times higher geometric mean serum ferritin compared with the PTB - patients (linear trend, $P<0.001)$ and 1.04 (95\% CI 0.84, 1.30), 1.13 (95\% CI $0.86,1.48)$ and 1.00 (95\% CI 0.82, 1.22; linear trend, $P=0.87$ ) in models 1 and 2 , respectively.

For serum sTfR, positive predictors were female sex, soil eating and $\mathrm{PTB}+$, and negative predictors were current smoking and HIV infection (Table 5, model 1). Age, alcohol consumption and $S$. mansoni and hookworm infection were not predictors. Serum ACT levels above $0.4 \mathrm{~g} / 1$ were associated with $0.4-0.6 \mathrm{mg} / \mathrm{l}$ higher serum sTfR levels (model 2). If expressed as a dichotomous variable, serum ACT above 0.4 was associated with $0.46(95 \%$ CI $0.04,0.89) \mathrm{mg} / \mathrm{l}$ or 1.12 (95\% CI 1.01, 1.25) times higher serum sTfR (not shown).

The inclusion of elevated serum ACT seemed to explain some of the effects of sputum-positive tuberculosis. Low, moderate and heavy culture intensities were associated with $0.54,0.22$ and $0.56 \mathrm{mg} / \mathrm{l}$ higher serum sTfR compared with the PTB - patients (model 1). However, with serum ACT controlled for, the corresponding regression coefficients declined to $0.45,0.07$ and 0.41 .

\section{Discussion}

We found that serum ACT between $0.4-0.5$ and above $0.5 \mathrm{~g} / 1$ was associated with approximately 1.5 and 3 times higher serum ferritin, and 6 and $15 \mathrm{~g} / \mathrm{l}$ lower $\mathrm{Hb}$, as in previous studies $^{(19)}$. Serum ACT is an acute- phase protein produced in hepatocytes in response to infections, and mediated by IL-6 ${ }^{(22)}$. By adjusting for elevated serum ACT, we attempted to explain the variation in serum ferritin and $\mathrm{Hb}$ due to infection, through IL-6-mediated hepcidin production. The recently discovered peptide hepcidin is a key Fe-regulatory hormone ${ }^{(23)}$, which is released from hepatocytes in response to $\mathrm{Fe}$ and oxygen. It degrades the membrane $\mathrm{Fe}$ exporter, ferroportin, thereby blocking the release of Fe from enterocytes, macrophages and hepatocytes. By contrast, Fe deficiency, anaemia and hypoxaemia suppress hepcidin production, there by increasing dietary $\mathrm{Fe}$ absorption and release of $\mathrm{Fe}$ to plasma. Interestingly, inflammation induces hepcidin production, mediated by the inflammatory cytokine IL-6. This results in sequestration of $\mathrm{Fe}$ in the stores and Fe-limited erythropoiesis, and eventually anaemia of inflammation ${ }^{(23)}$.

The serum concentration of the acute- phase reactants, such as C-reactive protein, $\alpha_{1}$-acid glycoprotein and ACT, has been used to adjust for the effect of the APR on the markers of micronutrient status when assessing the prevalence of deficiency in an apparently healthy population ${ }^{(7)}$. The acutephase reactants differ with respect to magnitude, timing and duration of the response, with ACT and $\alpha_{1}$-acid glycoprotein having a more delayed response, and a combination of the acute- phase reactants may be needed to account for different stages of the response ${ }^{(8)}$. 
Table 4. Predictors of serum ferritin ( $\mu \mathrm{g} / \mathrm{l}, \log _{10}$ transformed) with regression coefficients $\left(10^{\mathrm{B}}\right), 95 \% \mathrm{Cl}$ and the corresponding $P$ values. Elevated serum $\alpha_{1}$-antichymotrypsin (ACT) was adjusted for in model 2 , but not in model $1^{\text {* }}$

\begin{tabular}{|c|c|c|c|c|c|c|}
\hline & \multicolumn{3}{|c|}{ Model 1} & \multicolumn{3}{|c|}{ Model 2} \\
\hline & $10^{\mathrm{B}}$ & $95 \% \mathrm{Cl}$ & $P$ & $10^{\mathrm{B}}$ & $95 \% \mathrm{Cl}$ & $P$ \\
\hline Female sex $\dagger$ & 0.62 & $0.51,0.75$ & $<0.001$ & 0.63 & $0.54,0.74$ & $<0.001$ \\
\hline Alcohol drinking $\dagger$ & 1.25 & $1.04,1.49$ & 0.02 & 1.23 & $1.06,1.43$ & 0.007 \\
\hline \multicolumn{7}{|l|}{ Smokingt } \\
\hline Past & $1 \cdot 26$ & $1.00,1.58$ & 0.05 & $1 \cdot 26$ & $1.03,1.52$ & 0.02 \\
\hline Current & 1.34 & $1.02,1.77$ & 0.04 & 1.15 & $0.91,1.45$ & 0.25 \\
\hline Soil eating $\dagger$ & 0.47 & $0.32,0.69$ & $<0.001$ & 0.58 & $0.42,0.81$ & 0.001 \\
\hline \multicolumn{7}{|l|}{ Infections } \\
\hline PTB $+\dagger, \ddagger$ & 1.51 & $1.22,1.85$ & $<0.001$ & 1.06 & $0.88,1.27$ & 0.55 \\
\hline HIV† & 1.86 & $1 \cdot 56,2 \cdot 21$ & $<0.001$ & 1.90 & $1 \cdot 65,2 \cdot 19$ & $<0.001$ \\
\hline Schistosoma mansonit & 0.76 & $0.64,0.90$ & 0.001 & 0.86 & $0.74,0.99$ & 0.03 \\
\hline Hookworm† & 0.74 & $0.60,0.92$ & 0.005 & 0.77 & $0.65,0.92$ & 0.004 \\
\hline \multicolumn{7}{|l|}{ Serum ACT $(g / l) \S$} \\
\hline $0.4-0.6$ & - & & & 1.44 & $1 \cdot 10,1.86$ & 0.009 \\
\hline $0.6-0.8$ & - & & & 2.75 & $2 \cdot 13,3 \cdot 62$ & $<0.001$ \\
\hline $0.8-1 \cdot 0$ & - & & & 4.00 & $3.03,5.29$ & $<0.001$ \\
\hline$>1.0$ & - & & & 6.50 & $4.88,8.66$ & $<0.001$ \\
\hline
\end{tabular}

We found that serum ACT was highly elevated, with a mean of $0.72 \mathrm{~g} / 1$ and $81.9 \%$ above $0.4 \mathrm{~g} / \mathrm{l}$. This can be compared with $0.32 \mathrm{~g} / \mathrm{l}$ and $8.6 \%$, respectively, found in a community-based study among almost 1500 apparently healthy adults from the same area ${ }^{(24)}$.

While serum ACT was generally high among the PTB patients, it was the highest among the PTB + patients in whom it increased with bacterial intensity. There are several explanations for the lower serum ACT among the PTBpatients, which is a heterogeneous group of patients. Most of the PTB - patients probably had mild TB, and a correspondingly mild APR. Some may have had advanced HIV infection, with severe immune suppression, which makes them unable to expectorate mycobacteria ${ }^{(25)}$, as well as raising an appropriate APR. Still others may not have had PTB, but Pneumocystis carinii/jirovecii or other atypical pneumonia, probably due to advanced HIV infection. This is conceivable, since the prevalence of HIV was higher among the PTBpatients compared with the PTB + ones, and viral load was significantly higher among the HIV-infected PTB-patients compared with the PTB + ones. The lack of difference in serum ACT by HIV infection was also seen in the community-based study in the same area ${ }^{(24)}$, and among pregnant Zimbabwean women ${ }^{(26)}$.

Table 5. Predictors of serum soluble transferrin receptor $(\mathrm{mg} / \mathrm{l})$ with regression coefficients $(\mathrm{B}), 95 \% \mathrm{Cl}$ and the corresponding $P$ values. Elevated serum $\alpha_{1}$-antichymotrypsin (ACT) was adjusted for in model 2, but not in model $1^{*}$

\begin{tabular}{|c|c|c|c|c|c|c|}
\hline \multirow{4}{*}{$\begin{array}{l}\text { Female sex } \dagger \\
\text { Smoking }\end{array}$} & \multicolumn{3}{|c|}{ Model 1} & \multicolumn{3}{|c|}{ Model 2} \\
\hline & \multirow{3}{*}{$\begin{array}{c}B \\
0.28\end{array}$} & $95 \% \mathrm{Cl}$ & \multirow{3}{*}{$\frac{P}{0.04}$} & \multirow{3}{*}{$\begin{array}{l}B \\
0.26\end{array}$} & $95 \% \mathrm{Cl}$ & \multirow{3}{*}{$\frac{P}{0.06}$} \\
\hline & & $0.01, \quad 0.55$ & & & $-0.01, \quad 0.53$ & \\
\hline & & & & & & \\
\hline Past & -0.18 & $-0.51, \quad 0.14$ & 0.27 & -0.20 & $-0.53, \quad 0.12$ & 0.22 \\
\hline Current & -0.68 & $-1.05,-0.30$ & $<0.001$ & -0.71 & $-1.08,-0.33$ & $<0.001$ \\
\hline Soil eatingt & 0.49 & $-0.07, \quad 1.05$ & 0.08 & 0.52 & $-0.03, \quad 1.08$ & 0.07 \\
\hline PTB + †, & 0.48 & $0.19, \quad 0.78$ & 0.001 & 0.37 & $0.06, \quad 0.68$ & 0.02 \\
\hline $\mathrm{HIV} \dagger$ & -0.21 & $-0.44, \quad 0.02$ & 0.07 & -0.21 & $-0.44, \quad 0.03$ & 0.08 \\
\hline \multicolumn{7}{|c|}{ Serum ACT $(g / l) \S$} \\
\hline $0.4-0.6$ & & & & 0.43 & $-0.03, \quad 0.89$ & 0.07 \\
\hline $0.6-0.8$ & & & & 0.56 & $0.11, \quad 1.01$ & 0.02 \\
\hline $0.8-1.0$ & & & & 0.62 & $0.15, \quad 1.10$ & 0.01 \\
\hline$>1.0$ & & & & 0.35 & $-0.14, \quad 0.85$ & 0.16 \\
\hline
\end{tabular}


Although serum ferritin is considerably elevated among PTB patients, our data suggest that it may be elevated in a predictable manner. As shown, log serum ferritin increased linearly with serum ACT above $0.4 \mathrm{~g} / \mathrm{l}$. With other predictors in the model, serum ACT between 0.4-0.6, 0.6-0.8, 0.8-1.0 and above $1.0 \mathrm{~g} / \mathrm{l}$ was associated, respectively, with $1.4,2.8$, 4.0 and 6.5 times higher serum ferritin. The effect of serum ACT between $0.4-0.6 \mathrm{~g} / \mathrm{l}(1.44,95 \%$ CI $1.10,1.86)$ on serum ferritin was roughly similar to that estimated based on the data from a community-based study in the same area $(1.98,95 \% \text { CI } 1.68,2 \cdot 32)^{(24)}$.

Serum sTfR has been considered to be unaffected by the APR as assessed by serum C-reactive protein ${ }^{(27,28)}$. However, other studies suggest that also serum sTfR is affected by the $\mathrm{APR}^{(6)}$. A recent cross-sectional study among Zimbabwean children found that serum sTfR increased with increasing serum C-reactive protein, but also serum IL- $6^{(5)}$. We used serum ACT, induced by IL-6 ${ }^{(29)}$, as a measure of the APR, and found a threshold effect, i.e. that serum ACT above $0.4 \mathrm{~g} / \mathrm{l}$ was associated with $0.46 \mathrm{mg} / \mathrm{l}$ higher serum sTfR. Since different assays give different results, it may be more useful to refer to a 1.12 times increase with serum ACT above $0.4 \mathrm{~g} / \mathrm{l}$. Elevated serum ACT partially explained the effect of PTB+, but not of the other predictors in the model, and did not increase the proportion of the variance explained.

\section{Pulmonary tuberculosis, HIV and helminth infections}

Compared with the PTB - patients, serum ferritin was $50 \%$ higher in the PTB + patients, and increased with bacterial intensity. However, these relationships were fully explained by elevated serum ACT. By contrast, HIV infection was associated with almost twice as high levels of serum ferritin, which was not mediated by the APR, as HIV infection per se may not precipitate an $\mathrm{APR}^{(26)}$. The effect of HIV infection on serum ferritin probably reflects a genuine and slower effect on Fe status, as Fe becomes sequestered in the stores as a consequence of the depressed red cell synthesis in the bone marrow. $S$. mansoni and hookworm infection were both associated with lower serum ferritin. An established hookworm infection results in the loss of blood, and subsequently depletion of $\mathrm{Fe}$ stores, although the initial infection may cause an immune/acute-phase-response-mediated anaemia. S. mansoni infection is caused by a blood-dwelling fluke, and its effects on $\mathrm{Hb}$ could be mediated through haemolysis and suppressed erythropoiesis as well as the loss of blood, which will have opposite effects on serum ferritin.

Higher serum sTfR was seen among the PTB+ patients, and this did not change with elevated serum ACT accounted for in the analysis, although elevated serum ACT itself was associated with $0.46 \mathrm{mg} / \mathrm{l}$ higher concentrations. HIV infection, by contrast, was associated with marginally significantly lower serum sTfR.

\section{Other predictors}

The females had serum ferritin levels that were two-thirds that of the males, and higher serum STfR, reflecting the higher requirement of women of reproductive age, due to menstrual losses, and the losses due to frequent reproductive cycles.
The higher serum ferritin in smokers was similar to what was reported from a study among the $\mathrm{PTB}+$ patients in South Africa ${ }^{(30)}$. Smoking is a source of $\mathrm{Fe}^{(31)}$, but not likely to affect the total body Fe. However, Fe may accumulate in lung macrophages and promote the growth of mycobacteria ${ }^{(32)}$, and thus worsen the outcome of the infection. In addition, smoking per se may cause an $\mathrm{APR}^{(33)}$. This may explain the association we found, in that the higher serum ferritin was partially explained by the APR. However, this does not explain the higher levels in previous smokers, which were independent of serum ACT. By contrast, the considerably lower serum sTfR in current smokers seemed to be independent of serum ACT.

Consumption of alcoholic beverage was widespread both in the female and male patients, mainly as traditional beer brewed from maize, cassava, millet and sorghum. Alcohol consumption was a positive predictor of serum ferritin, but not of serum sTfR, and this was neither mediated nor confounded by the APR. Although socio-economic confounding cannot be excluded, the higher serum ferritin could also be due to alcohol-induced liver damage ${ }^{(34)}$, which may not necessarily be mediated by an APR. Alternatively, it could reflect larger Fe stores, due to the enhancing effect of alcohol on $\mathrm{Fe}$ absorption ${ }^{(35)}$, or the beverage could contain Fe from the raw material or the fermentation vessel. In the same community, alcohol consumption has previously been shown to be associated with not only higher serum ferritin but also higher $\mathrm{Hb}^{(24)}$, which may support the hypothesis that the association reflects a higher intake of $\mathrm{Fe}$.

The prevalence of soil eating among PTB patients, $10 \%$ in the females and $0.8 \%$ in the males, was lower than in the 18.8 and $0.4 \%$, respectively, found in the community-based study in the same study area ${ }^{(24)}$. In accordance with the findings from a number of studies among children ${ }^{(36)}$ and pregnant women ${ }^{(37)}$, we found that soil eating was associated with lower serum ferritin. However, we also found an association with higher serum sTfR. Yet, it is not clear whether low Fe stores cause a craving for soil or whether soil reduces Fe absorption ${ }^{(38,39)}$.

\section{Conclusion}

Although the substantial APR among PTB patients affects the direct measures of storage and tissue $\mathrm{Fe}$, a number of known or biologically plausible predictors still explain a considerable proportion of the variation. As suggested previously ${ }^{(40)}$, it may be possible to develop an algorithm, based on one or several acute- phase proteins, which will allow to assess the $\mathrm{Fe}$ status during infections.

\section{Acknowledgements}

DBL Centre for Health Research and Development and DANIDA (grant no. 91072) funded the study. The authors would like to acknowledge all health staff from the health facilities, laboratories and National Institute for Medical Research, Mwanza, for their contribution to the study. We thank the PTB patients for consenting to participate in the study.

H. F., N. R., P. M., A. B. A., W. M. and J. C. designed the study and were responsible for the planning, coordination and supervision of the field activities. P. K. and H. K. were responsible for the laboratory analyses. H. F. and C. B. K. did the 
initial data analyses. H. F. did the final data analyses and wrote the first draft of the manuscript. All authors were involved in the interpretation of the results and contributed to the final version of the manuscript.

None of the authors have conflicts of interests.

\section{References}

1. Cook JD \& Skikne BS (1982) Serum ferritin: a possible model for the assessment of nutrient stores. Am J Clin Nutr 35, $1180-1185$

2. WHO \& CDC (2005) Assessing the Iron Status of Populations. Report of a Joint WHO/CDC Technical Consultation on the Assessment of Iron Status at the Population Level. Geneva: World Health Organization and Centers for Disease Control and Prevention.

3. Witte DL (1991) Can serum ferritin be effectively interpreted in the presence of the acute-phase response? Clin Chem 37, 484-485.

4. Cook JD, Skikne BS \& Baynes RD (1993) Serum transferrin receptor. Annu Rev Med 44, 63-74.

5. Kasvosve I, Gomo ZA Nathoo KJ, et al. (2006) Association of serum transferrin receptor concentration with markers of inflammation in Zimbabwean children. Clin Chim Acta 371, 130-136.

6. Beesley R, Filteau S, Tomkins A, et al. (2000) Impact of acute malaria on plasma concentrations of transferrin receptors. Trans $R$ Soc Trop Med Hyg 94, 295-298.

7. Thurnham DI, Mburu AS, Mwaniki DL, et al. (2005) Micronutrients in childhood and the influence of subclinical inflammation. Proc Nutr Soc 64, 502-509.

8. Thurnham DI, Mburu AS, Mwaniki DL, et al. (2008) Using plasma acute-phase protein concentrations to interpret nutritional biomarkers in apparently healthy HIV-1-seropositive Kenyan adults. Br J Nutr 1-9.

9. Range N, Andersen AB, Magnussen P, et al. (2005) The effect of micronutrient supplementation on treatment outcome in patients with pulmonary tuberculosis: a randomized controlled trial in Mwanza, Tanzania. Trop Med Int Health 10, 826-832.

10. Range N, Changalucha J, Krarup H, et al. (2006) The effect of multi-vitamin/mineral supplementation on mortality during treatment of pulmonary tuberculosis: a randomised two-bytwo factorial trial in Mwanza, Tanzania. Br J Nutr 95, 762-770.

11. Ministry of Health URoT (1995) Manual of the National Tuberculosis and Leprosy Programme (NTLP). Geneva: WHO.

12. World Health Organization (2003) Treatment of Tuberculosis: Guidelines for National Programmes. Geneva: WHO.

13. Githui W, Kitui F, Juma ES, et al. (1993) A comparative study on the reliability of the fluorescence microscopy and ZiehlNeelsen method in the diagnosis of pulmonary tuberculosis. East Afr Med J 70, 263-266.

14. Peters PA, El Alamy M, Warren KS, et al. (1980) Quick kato smear for field quantification of Schistosoma mansoni eggs. Am J Trop Med Hyg 29, 217-219.

15. Peters PA, Mahmoud AA, Warren KS, et al. (1976) Field studies of a rapid, accurate means of quantifying Schistosoma haematobium eggs in urine samples. Bull World Health Organ 54, 159-162.

16. Lwambo NJ, Siza JE, Brooker S, et al. (1999) Patterns of concurrent hookworm infection and schistosomiasis in schoolchildren in Tanzania. Trans $R$ Soc Trop Med Hyg 93, 497-502.

17. Stoltzfus RJ \& Dreyfuss ML (1998) Guidelines for The Use of Iron Supplements to Prevent and Treat Iron Deficiency Anemia. Geneva: INACG/WHO/UNICEF.

18. Krarup HB, Drewes AM \& Madsen PH (1998) A quantitative HCV-PCR test for routine diagnostics. Scand J Clin Lab Invest 58, 415-422.
19. Friis H, Gomo E, Koestel P, et al. (2001) HIV and other predictors of serum folate, serum ferritin, and hemoglobin in pregnancy: a cross-sectional study in Zimbabwe. Am J Clin Nutr 73, 1066-1073.

20. Range N, Magnussen P, Mugomela A, et al. (2007) HIV and parasitic co-infections in tuberculosis patients: a cross-sectional study in Mwanza, Tanzania. Ann Trop Med Parasitol 101, 343-351.

21. World Health Organization (2002) Prevention and Control of Schistosomiasis and Soil-transmitted Helminthiasis. Geneva: WHO.

22. Castell JV, Gomez-Lechon MJ, David M, et al. (1989) Interleukin- 6 is the major regulator of acute phase protein synthesis in adult human hepatocytes. FEBS Lett 242, 237-239.

23. Nemeth E \& Ganz T (2006) Regulation of iron metabolism by hepcidin. Annu Rev Nutr 26, 323-342.

24. Malenganisho W, Magnussen P, Vennervald BJ, et al. (2007) Intake of alcoholic beverages is a predictor of iron status and hemoglobin in adult Tanzanians. J Nutr 137, 2140-2146.

25. Ellner JJ (1997) Review: the immune response in human tuberculosis - implications for tuberculosis control. J Infect Dis 176, 1351-1359.

26. Friis H, Gomo E, Koestel P, et al. (2001) HIV and other predictors of serum beta-carotene and retinol in pregnancy: a crosssectional study in Zimbabwe. Am J Clin Nutr 73, 1058-1065.

27. Asobayire FS, Adou P, Davidsson L, et al. (2001) Prevalence of iron deficiency with and without concurrent anemia in population groups with high prevalences of malaria and other infections: a study in Cote d'Ivoire. Am J Clin Nutr 74, 776-782.

28. Verhoef H, West CE, Ndeto P, Burema J, Beguin Y \& Kok FJ (2001) Serum transferrin receptor concentration indicates increased erythropoiesis in Kenyan children with asymptomatic malaria. Am J Clin Nutr 74, 767-775.

29. Berninger RW (1985) Protease inhibitors of human plasma. Alpha 1-antichymotrypsin. J Med 16, 101-128.

30. Plit ML, Theron AJ, Fickl H, et al. (1998) Influence of antimicrobial chemotherapy and smoking status on the plasma concentrations of vitamin $\mathrm{C}$, vitamin $\mathrm{E}$, beta-carotene, acute phase reactants, iron and lipid peroxides in patients with pulmonary tuberculosis. Int J Tuberc Lung Dis 2, 590-596.

31. Mateos F, Brock JH \& Perez-Arellano JL (1998) Iron metabolism in the lower respiratory tract. Thorax 53, 594-600.

32. Boelaert JR, Gomes MS \& Gordeuk VR (2003) Smoking, iron, and tuberculosis. Lancet 362, 1243-1244.

33. Das I (1985) Raised C-reactive protein levels in serum from smokers. Clin Chim Acta 153, 9-13.

34. Fletcher LM, Halliday JW \& Powell LW (1999) Interrelationships of alcohol and iron in liver disease with particular reference to the iron-binding proteins, ferritin and transferrin. $J$ Gastroenterol Hepatol 14, 202-214.

35. Hallberg L \& Hulthen L (2002) Perspectives on iron absorption. Blood Cells Mol Dis 29, 562-573.

36. Geissler PW, Mwaniki DL, Thiong'o F, et al. (1998) Geophagy, iron status and anaemia among primary school children in Western Kenya. Trop Med Int Health 3, 529-534.

37. Geissler PW, Mwaniki D, Thiong F, et al. (1998) Geophagy as a risk factor for geohelminth infections: a longitudinal study of Kenyan primary schoolchildren. Trans $R$ Soc Trop Med Hyg 92, 7-11.

38. Harvey PW, Dexter PB \& Darnton-Hill I (2000) The impact of consuming iron from non-food sources on iron status in developing countries. Public Health Nutr 3, 375-383.

39. Moore DF Jr \& Sears DA (1994) Pica, iron deficiency, and the medical history. Am J Med 97, 390-393.

40. Northrop-Clewes CA (2008) Interpreting indicators of iron status during an acute phase response - lessons from malaria and human immunodeficiency virus. Ann Clin Biochem 45, $18-32$. 